\title{
Mitigasi Beban Fosfor dari Kegiatan Budidaya dengan Penebaran Ikan Bandeng (Chanos chanos) Di Waduk Cirata, Jawa Barat
}

\section{Mitigation of Phosphorus Loading from Aquaculture Activity by Milk Fish (Chanos chanos) Stocking at Cirata, Reservoir, West Java}

\author{
ANDRI WARSA, JONI HARIYADI DAN LISMINING PUJIYANI ASTUTI \\ Balai Riset Pemulihan Sumber daya Ikan \\ Jalan Cilalawi No 1 Jatiluhur, Purwakarta, Jawa Barat 41152 \\ andriwarsa@yahoo.co.id
}

\begin{abstract}
The phosphorus loading from aquaculture activity as a product of floating net cages (KJA) in Cirata Reservoir have exceeded the carrying capacity of the aquatic ecology. This results in a decrease in water quality which is characterized by uncontrolled phytoplankton growth. The stocking of fish is one of the ways used in the improvement of the aquatic environment resulting eutrophication. Phosphorus which is wasted from cultivation activity will be utilized by phytoplankton for its growth. The phytoplankton can be utilized by planktivorous fish as its natural feed. One type of fish that can be used for stocking is a planktivora fish as milkfish (Chanos chanos). The purpose of this study was to estimate the load of phosphorus and calculate the number of milkfish seeds which are planktivorous fish that can be stocked with the aim of reducing phosphorus waste from aquaculture activities in Cirata Reservoir, West Java. The result showed that $P$ load from cultivation activity at Cirata Reservoir was 1,206 tons/year. The concentration of chlorophyll-a and the primary productivity produced by the $P$ load from the cultivation activities were $28.6 \mathrm{mg} / \mathrm{m}^{3}$ and $364.6 \mathrm{gC} / \mathrm{m}^{2} /$ year respectively. The number of milkfish seeds that can be stocked as an effort to utilize the load of phosphorus as much as 1.8 million/year. The $P$ load can be reduced based on estimation of harvested fish biomass and phosphor requirement for milkfish of 11.52 ton/year.
\end{abstract}

Keywords: Cirata Reservoir, phosphorus loading, stocking, milkfish

\begin{abstract}
ABSTRAK
Beban masukkan fosfor $(\mathrm{P})$ dari kegiatan budidaya ikan dalam keramba jaring (KJA) dari pakan yang terbuang dan sisa metabolisme ikan di Waduk Cirata telah melebihi daya dukung ekologi perairan. Hal ini berdampak pada penurunan kualitas perairan yang ditandai oleh pertumbuhan fitoplankton yang tidak terkendali. Penebaran ikan merupakan salah satu cara yang digunakan dalam perbaikan lingkungan perairan akibat dari eutrofikasi. Fosfor di perairan dimanfaatkan oleh fitoplankton untuk pertumbuhannya. Fitoplankton tersebut dapat dimanfaatkan oleh ikan planktivora sebagai pakan alaminya.Salah satu jenis ikan yang dapat ditebar (stocking) adalah ikan planktivora yaitu ikan bandeng (Chanos chanos). Tujuan penelitian ini adalah untuk mengestimasi beban masukkan fosfor serta menghitung jumlah benih ikan bandeng yang dapat ditebar dengan tujuan pengurangan limbah fosfor dari kegiatan budidaya di Waduk Cirata, Jawa Barat. Hasil penelitian menunjukkan beban P yang berasal dari kegiatan budidaya di Waduk Cirata sebesar 1.206 ton/tahun. Konsentrasi klorofil-a dan produktivitas primer yang dihasilkan oleh beban $P$ dari kegiatan budidaya masing-masing sebesar $28,6 \mathrm{mg} / \mathrm{m}^{3}$ dan $364,6 \mathrm{gC} / \mathrm{m}^{2} / \mathrm{tahun}$. Jumlah benih ikan bandeng yang dapat ditebar sebagai upaya pemanfaatan beban masukkan fosfor sebanyak 1,8 juta ekor/tahun. Beban P yang mampu dikurangi berdasarkan estimasi biomassa ikan yang dipanen dan kebutuhan fosfor untuk ikan bandeng sebesar ton 11,52 ton/tahun.
\end{abstract}

Kata kunci: Waduk Cirata, beban fosfor, penebaran, bandeng 


\section{PENDAHULUAN}

\subsection{Latar Belakang}

Waduk Cirata merupakan waduk serba guna dengan keragaman jenis ikan tinggi yang terdiri dari 6 spesies ikan asli dan 12 spesies ikan introduksi(1). Kegiatan perikanan budidaya dan tangkap merupakan fungsi sekunder dari Waduk

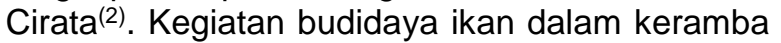
jaring apung (KJA) di Waduk Cirata telah melebihi daya dukung ekologi lingkungan perairan $^{(3)}$ dengan beban masukkan fosfor mencapai 11,5 juta ton/tahun(4). Dampak negatif yang timbul adalah degradasi lingkungan yang ditandai penurunan kecerahan dan konsentrasi oksigen terlarut serta peningkatan konsentrasi nutrient $\mathrm{N}$ dan $\mathrm{P}$ di perairan ${ }^{(5)}$. Hal ini berdampak pada sering terjadinya kematian massal ikan di Waduk Cirata(6). Beban masukkan fosfor kedalam perairan dapat menyebabkan peningkatan kesuburan perairan atau eutrofikasi(7) dan telah menjadi permasalahan yang dihadapi oleh sebagian besar badan air(8).

Fosfor merupakan nutrien pembatas untuk pertumbuhan fitoplankton dan menyebabkan meningkatnya produktivitas primer perairan(9). Produktivitas primer perairan dapat digambarkan oleh klorofil-a dan kelimpahan fitoplankton ${ }^{(10)}$. Peningkatan biomassa fitoplankton dapat dimanfaatkan dengan penebaran ikan planktivora(11). Ikan nila merupakan jenis ikan yang memanfaatkan fitoplankton sebagai pakan utama di Waduk Cirata ${ }^{(12,13)}$. Oleh karena itu peningkatan produksi ikan alami dapat dilakukan dengan penebaran jenis tertentu yang dapat mengisi relung yang belum termanfaatkan tersebut ${ }^{(14)}$. Selain itu penebaran ikan merupakan salah satu cara yang dapat digunakan untuk memperbaiki kualitas lingkungan perairan secara biologi(15). Penebaran ikan nilem (Osteochilus vittatus) telah dilakukan di danau Maninjau sebagai agen pembersih hayati ${ }^{(16)}$. Penebaran ikan mola atau Silver carp (Hypophthalmichthys molitrix) dengan ukuran dan jumlah yang tepat dapat menurunkan kelimpahan fitoplankton dari kelas cyanophycea dan chlorophycea(17). Ikan bandeng (Chanos chanos) yang diintroduksi ke Danau Laguna De Bay, Filipina mampu hidup dan tumbuh dengan baik di perairan. Ikan ini dapat mencapai ukuran konsumsi (250-300 gr) dalam waktu 4-8 bulan ${ }^{(18)}$.

\subsection{Tujuan Penelitian}

Tujuan penelitian ini adalah untuk mengestimasi beban masukkan fosfor dari kegiatan budiaya serta menghitung jumlah benih ikan bandeng (Chanos chanos) yang dapat ditebar dalam rangka mitigasi limbah fosfor dari kegiatan budidaya di Waduk Cirata, Jawa Barat.

\section{BAHAN DAN METODE}

\subsection{Waktu dan tempat}

Data yang digunakan dalam penelitian ini merupakan data primer dan data sekunder. Data primer merupakan adalah data beberapa aspek budidaya yaitu jenis ikan, jumlah pakan, biomassa saat panen dan waktu yang perlukan dalam satu periode pemeliharaan diperoleh melalui wawancara dengan pembudidaya. Wawancara dilakukan pada 25 responden terpilih secara acak yang mewakili zona budidaya di Kabupaten Bandung Barat, Cianjur. Responden dipilih secara sengaja (purposive sampling) berdasarkan atas azas keterwakilan ${ }^{(19)}$. Wawancara yang dilakukan dengan bantuan kuisioner. Penelitian dilakukan pada bulan Februari dan September 2016. Jumlah keramba yang beroperasi ditentukan berdasarkan peta citra 2016 dari google earth pro.

Data sekunder diperoleh dari penelusuran pustaka dan dari instasi terkait. Data sekunder yang digunakan antara lain konsentrasi fosfor dalam pakan dan ikan, data hidromorfologi waduk (luas, kedalaman rata-rata, debit air masuk dan volume air) dan produksi ikan budidaya. Konsentrasi fosfor pada pakan dan ikan (nila, mas dan bawal) diperoleh dari Yosmaniar(19). Data hidrologimorfologi waduk diperoleh dari Badan Pengelola Waduk Cirata dan produksi ikan diperoleh dari Balai Besar Wilayah Sungai (BBWS) Citarum. Aspek biologi ikan bandeng yang meliputi parameter pertumbuhan meliputi panjang infiniti dan konstanta pertumbuhan serta pola pertumbuhan diperoleh dari hasil penelitian Tjahjo et a/(21)

Pendugaan konsentrasi klorofil-a berdasarkan beban fosfor dari kegiatan budidaya dihitung mengikuti persamaan dari Jones et al.(24)

log Error! Reference source not found.=0,76Error! Reference source not found. $-0,25$...

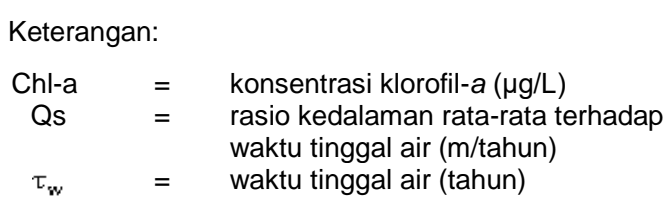


Pendugaan produktivitas primer berdasarkan beban masukkan fosfor mengikuti persamaan dari Vollenweider \& Dillon (1974)(25) sebagai berikut:

$\mathrm{PP}=420 \frac{10[\mathrm{~L}(\mathrm{p})]^{0,6}}{9+10[\mathrm{~L}(\mathrm{p})]^{0,6}}$

Keterangan:

$\mathrm{PP}=$ produktivitas primer $\left(\mathrm{gC} / \mathrm{m}^{2} /\right.$ tahun $)$

$\mathrm{L}(p)=$ beban masukkan fosfor total $\left(\mathrm{g} / \mathrm{m}^{2} /\right.$ tahun $)$

Potensi produksi ikan

Potensi produksi ikan sebagai dasar penebaran dihitung berdasarkan parameter klorofil-a dengan persamaan dari Oglesby

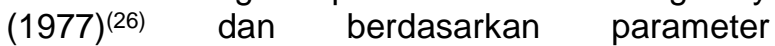
produktivitas primer dengan persamaan dari Almazan \& Boyd(27).

$$
\begin{array}{lll}
\log Y_{d} & : & -1.92+1.17 \log \text { Chl-a } \\
\text { Ypp } & : & -166,64+354,6 \text { Xp }-18,06 X^{2} . . .
\end{array}
$$

Keterangan:

$$
\begin{array}{ll}
\mathrm{Yd}= & \begin{array}{l}
\text { potensi produksi berdasarkan klorofil-a } \\
\left(\mathrm{g} / \mathrm{m}^{2} / \mathrm{tahun}\right)
\end{array} \\
\mathrm{Ypp} & =\begin{array}{l}
\text { potensi produksi berdasarkan produktivitas } \\
\text { primer }(\mathrm{kg} / \mathrm{ha} / \mathrm{tahun})
\end{array}
\end{array}
$$

Estimasi jumlah dan ukuran benih serta hasil panen

Jumlah benih ikan planktivora yang dapat ditebar di dihitung berdasarkan persamaan dari Welcomme \& Bartley(28) dengan persamaan sebagai berikut:

\section{Error! Reference source not found.}

keterangan:

$\begin{array}{lll}\mathrm{S} & = & \text { jumlah penebaran (ekor/ha) } \\ \mathrm{q} & = & \text { potensi produksi ikan }(\mathrm{kg} / \mathrm{ha} / \mathrm{tahun}) \\ \mathrm{p} & = & \begin{array}{l}\text { proporsi hasil tangkapan jenis ikan yang } \\ \text { ditebar }(\%)\end{array} \\ \hat{\mathrm{w}} & = & \text { rata-rata berat ikan hasil tangkapan }(\mathrm{kg} / \mathrm{ekor}) \\ \mathrm{z} & = & \text { mortalitas total }\left(\operatorname{tahun}^{-1}\right) \\ \mathrm{t}_{\mathrm{c}} & = & \text { umur pada waktu tertangkap (tahun) } \\ \mathrm{t}_{\mathrm{o}} & = & \text { umur pada saat penebaran (tahun) }\end{array}$

Ukuran benih yang akan ditebar ditentukan berdasarkan ketersediaan ukuran benih serta mortalitas alami ikan. Mortalitas alami ikan berdasarkan ukuran dihitung dengan persamaan Chen \& Watanabe (1989) ${ }^{(29)}$.

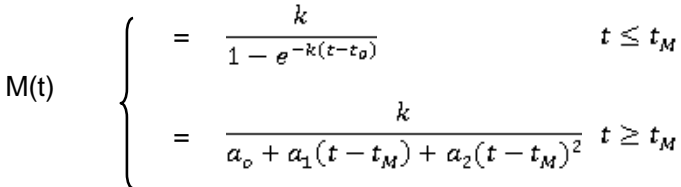

$$
\begin{aligned}
& \mathrm{t}_{\mathrm{M}} \quad=-\frac{1}{k} \ln \left(1-e^{k t_{0}}\right)+t_{0}
\end{aligned}
$$

Keterangan:

$$
\begin{array}{lll}
\mathrm{M}(\mathrm{t}) & = & \text { mortalitas alami pada umur } \mathrm{t} \text { (tahun) } \\
\mathrm{t}_{\mathrm{o}} \text { dan } \mathrm{t} & = & \begin{array}{l}
\text { umur teoritis ikan pada umur nol dan } \mathrm{t} \\
\text { (tahun) }
\end{array} \\
\mathrm{K} & =\begin{array}{l}
\text { konstanta pertumbuhan von bertalanffy } \\
\text { (per tahun) }
\end{array}
\end{array}
$$

Produksi ikan tebaran dihitung berdasarkan pada pendekatang dari King (1995)(30). Beban $P$ yang dapat dikurangi oleh ikan tebaran dihitung berdasarkan pada biomassa panen serta retensi $P$ ikan bandeng dengan persamaan Beveridge (1984) ${ }^{(31}$ dengan persamaan sebagai berikut:

$L P_{\text {ikan }}=L P_{\text {ling }}-($ Bix\%Pikan $) \times 1000$

$$
\begin{aligned}
& \text { Keterangan: } \\
& \mathrm{LP}_{\text {ikan }}=\text { pengurangan fosfor oleh ikan tebaran } \\
& \text { (kg/ton ikan) } \\
& \mathrm{P}_{\text {ling }}=\text { beban masukkan fosfor total dari kegiatan } \\
& \text { budidaya ( } \mathrm{kg} / \mathrm{ton} \text { ikan) } \\
& \mathrm{Bi}=\text { Biomassa ikan panen (ton ikan /tahun) } \\
& \% \mathrm{P}_{\text {ikan }}=\text { konsentrasi fosfor total pada ikan (\%) }
\end{aligned}
$$

\section{HASIL DAN PEMBAHASAN}

\subsection{Beban fosfor dari budidaya}

Ikan yang dipelihara di KJA adalah ikan mas (Cyprinus carpio), nila (Oreochromis niloticus) dan bawal (Colossoma macropomum) dengan menggunakan sistem jaring ganda. KJA lapisan pertama berukran $7 \times 7 \times 4 \mathrm{~m}$ sedangkan lapis kedua berukuran $14 \times 14 \times 9 \mathrm{~m}$. Ikan mas atau bawal dipelihara pada jaring lapis pertama sedangkan pada jaring kedua dipelihara ikan nila. Waktu yang diperlukan untuk satu periode pemeliharaan ikan mas dan bawal adalah 3,5-4 bulan sedangkan ikan nila selama 8 bulan. Ukuran benih ikan mas, bawal dan nila yang dipelihara masing-masing adalah 10; 12,5 dan 25 gr/ekor dengan biomassa masing-masing sebanyak 100, 80 dan $200 \mathrm{~kg} /$ petak. Ikan mas, nila dan bawal dipanen pada ukuran 250; 200 dan 250-500 g/ekor dengan biomassa masingmasing sebesar 1,3; 1,0 dan 0,3 ton/petak/periode.

Perhitungan beban $\mathrm{P}$ dari kegiatan budidaya ikan dalam KJA di Waduk Cirata di sajikan pada Tabel 1. Jumlah pakan yang digunakan dalam satu periode pemeliharaan sebanyak ton dengan 
produksi sebesar 1,6-1,8 ton/unit/periode sehingga nilai konversi pakan berkisar 1,33-1,69. Konsentrasi $\mathrm{P}$ pada pakan yang digunakan di
Waduk Cirata berkisar (Sukadi, 2010)(32). Retensi $P$ pada ikan mas, nila dan bawal masing-masing berkisar 0,$7 ; 0,9$ dan $0,86 \%$

Tabel 1. Perhitungan beban $P$ dari kegiatan budidaya ikan jaring ganda di Waduk Cirata

\begin{tabular}{|c|c|c|c|}
\hline No & Parameter & Satuan & Nilai \\
\hline 1 & Jumlah KJA & petak & 78.675 \\
\hline \multirow[t]{2}{*}{2} & Produksi & ton/tahun/petak & \\
\hline & $\begin{array}{l}\text { - mas + nila } \\
\text { - bawal + nila }\end{array}$ & & $\begin{array}{l}2,7 \\
3,5\end{array}$ \\
\hline \multirow[t]{2}{*}{3} & Jumlah pakan & ton/tahun/petak & \\
\hline & $\begin{array}{l}\text { - mas + nila } \\
\text { - bawal + nila }\end{array}$ & & $\begin{array}{l}4,6 \\
4,6\end{array}$ \\
\hline \multirow[t]{2}{*}{3} & Rasio konversi pakan & & \\
\hline & $\begin{array}{l}\text { - mas + nila } \\
\text { - bawal + nila }\end{array}$ & & $\begin{array}{l}1,7 \\
1,3\end{array}$ \\
\hline \multirow[t]{5}{*}{4} & Konsentrasi fosfor pada & $\%$ & \\
\hline & - Pakan & & 1,5 \\
\hline & - Mas & & 0,7 \\
\hline & - Bawal & & 0,9 \\
\hline & - Nila & & 0,9 \\
\hline \multirow[t]{2}{*}{5} & Beban fosfor dari & $\begin{array}{l}\mathrm{Kg} \mathrm{P} / \text { ton } \\
\text { ikan/tahun/petak }\end{array}$ & \\
\hline & $\begin{array}{l}\text { - mas + nila } \\
\text { - bawal + nila }\end{array}$ & & $\begin{array}{l}9,4 \\
2,4\end{array}$ \\
\hline \multirow[t]{2}{*}{6} & Produksi & ton ikan /tahun & \\
\hline & $\begin{array}{l}\text { - mas + nila } \\
\text { - bawal + nila }\end{array}$ & & $\begin{array}{r}96.817 \\
128.212\end{array}$ \\
\hline 7 & Total beban fosfor & ton $\mathrm{P} /$ tahun & 1.206 \\
\hline
\end{tabular}

Beban masukkan $\mathrm{P}$ dari aktivitas budidaya KJA di Waduk Cirata sebesar 1.206 ton/tahun atau lebih besar dibandingkan dengan hasil penelitian Garno(33) yaitu sebesar 1.041 ton/tahun. Hal ini karena produksi total ikan dan jumlah KJA yang beroperasi lebih besar pada penelitian ini. Namun beban $P$ untuk setiap unit KJA lebih rendah yang menandakan adanya perbaikan sistem budidaya di Waduk Cirata yaitu efisiensi pemberian pakan yang lebih baik dan penggunaan sistem jaring ganda pada pemeliharaan ikan. Pakan yang tidak termanfaatkan oleh ikan pada jaring pertama akan dimanfaatan oleh ikan yang dipelihara pada jaring kedua. Beban $P$ dari setiap petak KJA di Waduk Cirata yaitu 9,35 kgP/ton ikan atau lebih kecil jika dibandingkan dengan beban $P$ di Danau Maninjau yaitu 12,2 kgP/ton ikan(34). Pada jaring lapis kedua pada sistem jaring ganda dipelihara ikan nila yang memanfaatkan pakan yang terbuang dari budidaya ikan mas atau bawal pada jaring pertama. Sistem jaring ganda yang diterapkan di Waduk Cirata menyebabkan pakan yang terbuang dan nilai rasio konversi pakan (RKP) menjadi lebih kecil(35). Besarnya beban masukkan dari kegiatan budidaya dipengaruhi oleh nilai RKP, konsentrasi $\mathrm{P}$ pada pakan serta retensi $\mathrm{P}$ dari ikan yang dipelihara(22;36).

Fosfor merupakan nutien pembatas yang mempengaruhi konsentrasi klorofil-a dan produktivitas primer(37). Selain dipengaruhi oleh beban masukkan, konsentrasi $P$ diperairan juga dipengaruhi oleh hidromorfologi badan air yaitu luas, kedalaman rata-rata, dan laju pembilasan(38). Estimasi konsentrasi klorofil-a dan produktivitas primer akibat beban masukkan $P$ dari kegiatan budidaya di Waduk Cirata disajikan pad Tabel 2.

Tabel 2. Estimasi klorofil-a dan produktivitas primer di Waduk Cirata

\begin{tabular}{llll}
\hline No & Parameter & Satuan & Nilai \\
\hline 1. & Luas $(\mathrm{A})$ & $\left(10^{6} \mathrm{~m}^{2}\right)$ & 62 \\
2. & Kedalaman $(\mathrm{z})$ & $\mathrm{M}$ & 28,8 \\
3. & Laju pembilasan $(\rho)$ & tahun $^{-1}$ & 2,19 \\
4. & Retensi P $(\mathrm{R})$ & $\%$ & 0,4 \\
5. & Konsentrasi Klorofil-a & $\mathrm{mg} / \mathrm{m}^{3}$ & 28,6 \\
6. & Produktivitas primer & $\mathrm{gC} / \mathrm{m}^{2} /$ tahun & 364,6 \\
\hline
\end{tabular}

Konsentrasi klorofil-a dan produktivitas primer yang dihasilkan oleh beban $\mathrm{P}$ dari kegiatan budidaya masing-masing sebesar 28,6 
$\mathrm{mg} / \mathrm{m}^{3}$ dan 364,6 $\mathrm{gC} / \mathrm{m}^{2} /$ tahun. Konsentrasi klorofil-a dan produktivitas primer di Waduk Cirata ini lebih besar jika dibandingkan dengan Waduk Malahayu, Brebes ${ }^{(39)}$. Sumber P yang masuk ke Waduk Cirata selain dari aktivitas budidaya juga berasal dari tata guna lahan pada daerah tangkapan air melalui Sungai Citarum dan Waduk Saguling. Beban masukkan P dari kegiatan budidaya di Waduk Cirata lebih besar jika dibandingkan dengan beban masukkan $P$ dari tata guna lahan sekitar badan air(3).

\subsection{Estimasi jumlah, ukuran benih dan pengurangan $\mathbf{P}$ dengan penebaran}

Kemampuan ikan dalam memanfaatkan pakan alami yang tersedia serta biomassa ikan yang ditebar akan menentukan keberhasilan perbaikan lingkungan yang dilakukan dengan penebaran ${ }^{(40)}$. Daya dukung perairan terhadap jumlah benih yang ditebar dapat diestimasi berdasarkan potensi produksi ikan di perairan tersebut(41) yang ditentukan berdasarkan parameter klorofil-a dan produktivitas primer. Potensi produksi ikan berdasarkan klorofil-a dan produktivitas primer masing-masing adalah 83,8 dan $84,8 \mathrm{~kg} / \mathrm{ha} /$ tahun. Potensi produksi ini lebih kecil jika dibandingkan dengan potensi produksi perairan waduk di Asia pada umumnya yaitu sebesar $108 \mathrm{~kg} / \mathrm{ha} / \operatorname{tahun}^{(42 ; 43) \text {. }}$

Ikan bandeng merupakan jenis ikan planktivora yang dipilih untuk ditebar sebagai upaya perbaikan lingkungan perairan di Waduk Cirata. Hal ini didasarkan pada beberapa kriteria yaitu mempunyai rantai makanan yang pendek, mampu memanfaatakan fitoplankton sebagai pakan alaminya, laju pertumbuhan yang cepat, mampu memanfaatkan zona limnetik dan disukai oleh masyarakat(44;45). Jumlah ikan bandeng yang dapat ditebar sebanyak sebagai upaya pengurangan $\mathrm{P}$ di lingkungan perairan sebanyak 281 ekor/ha/tahun atau total sebanyak 1,8 juta ekor/tahun. Jumlah benih yang ditebar ini lebih besar jika dibandingkan dengan jumlah benih ikan bandeng yang ditebar di Waduk Sempor(46).

Ukuran ikan bandeng yang ditebar harus memiliki ukuran panjang total $10 \mathrm{~cm}$. Hal ini didasarkan pada nilai laju mortalitas yang semakin menurun dengan bertambahnya ukuran panjang total benih ikan yang ditebar(47). Laju mortalitas alami ikan bandeng pada ukuran 5 dan $10 \mathrm{~cm}$ masing-masing adalah 1,17 dan 0,72 tahun $^{-1}$. Ukuran panjang total ikan bandeng yang ditebar di Waduk Jatiluhur dan Waduk Sempor masing-masing berkisar 2,8-5,8 cm dan 3-5 $\mathrm{cm}^{(21 ; 46)}$. Ukuran benih ikan bandeng yang tersedia di Balai Benih Ikan (BBI) dan Unit perbenihan Rakyat (UPR) berukuran kurang dari $5 \mathrm{~cm}$. Oleh karena itu sebelum penebaran benih bandeng perlu dipelihara terlebih dahulu. Hal ini dilakukan untuk pembesaran benih agar mencapai ukuran siap tebar dan juga proses dalam rangka proses aklimatisasi. Penebaran ukuran yang $10 \mathrm{~cm}$ akan memberikan hasil panen dan pengurangan beban $P$ dilingkungan yang lebih besar dibandingkan dengan penebaran ukuran $5 \mathrm{~cm}$.

Panjang total ikan bandeng $30 \mathrm{~cm}$ dengan berat 200 g/ekor menghasilkan biomassa panen terbaik. Waktu yang diperlukan untuk mencapai ukuran panen tersebut adalah 5-5,5 bulan setelah penebaran (Gambar 2). Hal ini didukung oleh laju pertumbuhan ikan bandeng yang mencapai 4,0-5,5 cm/bulan(46) sehingga penebaran dapat dilakukan tiga kali dalam satu tahun.

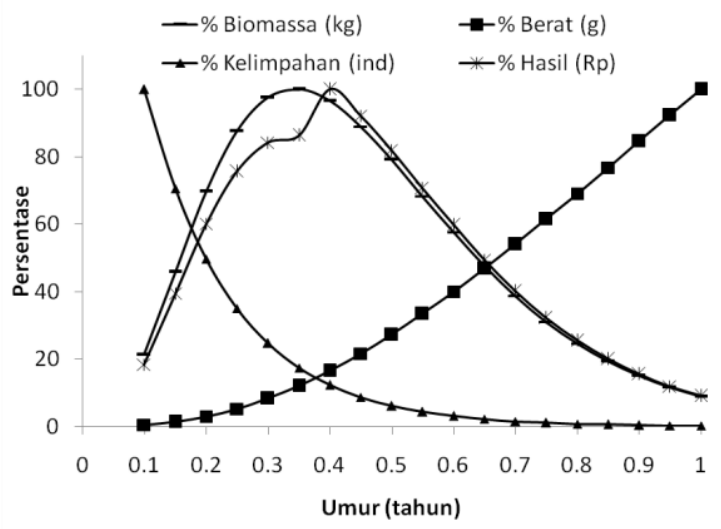

Gambar 2. Estimasi waktu dan ukuran panen ikan bandeng

Estimasi hasil panen ikan badeng tebaran sebesar di Waduk Cirata 532 ton/tahun. Berdasarkan retensi fosfor dalam tubuh ikan bandeng adalah $0,6-0,7 \%(48)$ maka beban $P$ yang dapat dikurangi dengan penebaran ikan bandeng sebanyak 11,2 ton/tahun atau sebanyak 2,3\%. Penebaran ikan bandeng dapat memperbaiki kualitas air di Waduk Jailuhur yang ditandai oleh penurunan konsentrasi orthofosfat dan nitrat serta tidak terjadinya blooming microcystis(49). Hal ini berkaitan dengan kemampuan dari ikan bandeng memanfaatkan phytoplankton dari kelas cyanophyceae dan chlorophycea sebagai pakan alaminya(50). Penebaran ikan planktivora lainnya seperti mola dan bighead carp (Aristichthys nobilis) dengan jumlah yang tepat dapat mengurangi kelimpahan 
fitoplankton dan meningkatkan kecerahan $(51 ; 52)$. $\mathrm{Hal}$ ini menandakan bahwa penebaran kedua jenis ikan tersebut dapat menurunkan status trofik perairan ${ }^{(53)}$

\section{KESIMPULAN}

Beban $P$ yang berasal dari kegiatan budidaya di Waduk Cirata sebesar 1.206 ton/tahun. Jumlah benih ikan bandeng yang dapat ditebar sebagai upaya pemanfaatan beban masukkan fosfor sebanyak 1,8 juta ekor/tahun dengan ukuran panjang total $10 \mathrm{~cm}$. Penebaran dapat dilakukan sebanyak tiga kali dalam satu tahun dengan estimasi panen untuk setiap kali penebaran adalah 532 ton. Beban $\mathrm{P}$ yang mampu dikurangi dengan penebaran ikan bandeng berdasarkan biomassa ikan yang dapat dipanen sebesar ton 11,52 ton

\section{PERSANTUNAN}

Tulisan ini merupakan hasil dari kegiatan Penelitian Optimalisasi Daya Dukung Perairan dan Revitalisasi Zonasi budidaya KJA di Waduk Kaskade Tahun Anggaran 2016.

\section{DAFTAR PUSTAKA}

1. Wahyuni, S., Sulistiono \& Affandi R. (2014). Distibusi secara spasial dan temporal ikan di Waduk Cirata, Jawa Barat. Jurnal Bumi Lestari, 14(1), 74-84.

2. Ibrahim, B., Suptijah, P., \& Aktinidia Y. (2013). Proses pengayaan nutrient limbah ikan Waduk Cirata dengan activator Gliocladium sp. Dan media kascing. Jurnal Pengolahan Hasil Perikanan Indonesia, 16(1), 33-41.

3. Garno, Y.S. (2002). Beban pencemaran limbah perikanan budidaya dan yutrofikasi di periaran waduk pada DAS Citarum. Jurnal Teknologi Ligkungan, 3(2), 112-120

4. Krismono A. S. N., Krismono., \& Kartamihardja, E. S. (2001). Dampak budidaya ikan dalam Keramba Jaring Apung terhadap peningkatan unsur $\mathrm{N}$ dan $\mathrm{P}$ diperairan Waduk saguling, Cirata dan Jatiluhur. Jurnal Penelitian Perikanan Indonesia, 7(2), 22-30.

5. Kartamihardja, E.S. (1991). Effects of intensive cage fish culture on the water chemistry of the Cirata Reservoirln west java, Indonesia. BIOTROP Spec. Publ 43, 161-173.

6. Suwedi, N., Alamsyah A. T., Sutjiningsih, D., \& Garno, Y. S. (2015). Kematian massal ikan di Waduk Cirata Pada Januari 2013. Limnotek, 22(1), 22-31.

7. Ahmed R., Shahabuddin, A. M., Habib, M.A.B., \& Yasmin, M.S. (2010). Impact of aquaculture practices in Naogaon Distric of Bangladesh. Research Journal of Fisheries and Hydrobiology, 5 (2), 56 65.

8. Ryding, S.O., \& Rast, W. (1989). The control of of eutrophication of lakes and reservoirs. The Parthenon Publishing Group. United Kingdom: 314p

9. Jose, A. S., \& Pasicola, S. A. (2013). Carrying capacity of net primary productivity of Laguna Lake, Philippines. Gl. ads. Res. J. Agric. Sci., 2(11), 289298.

10. Mujiyanto., Tjahjo D. W. H., \& Sugianti, Y. (2011). Hubungan antara kelimpahan fitoplankton dengan kosnetrasi N:P pada daerah keramba jaring apung (KJA) di Waduk Ir. H. Djuanda. Limnotek, 18(1), 15-25

11. Karim, M., Little, D.C., Kabir Md.S., Verdegem M.J.C., Telfer, T., \& Wahab M.D.A. (2011). Enhancing benefit from polycultures including tilapia (Oreochromis niloticus) within integrated pon-dike system: A paticipaory with households of varying socio-economic level in rural and peri-urban areas of Bangladesh. Aquaculture,314, 225-235.

12. Tjahjo, D. W. H., \& Purnamaningtyas, S. E. (2008). Kajian kebiasaan makanan, luas relung, dan interkasi antar jenis ikan di Waduk Cirata, Jawa Barat. Jurnal Iktiologi Indonesia, 8(2), 59-65.

13. Tjahjo, D, W, H., Nuroniah, $S$ \& Purnamaningtyas, S. E. (2001). Evaluasi limnology dan relung ekologi komunitas ikan untuk menentukan jenis ikan yang ditebar di Waduk Darma. Jurnal Penelitian Perikanan Indonesia, 7(1), 10-24.

14. Purnamaningtyas, S. E., \& Tjahjo, D. W. H. (2009). Kebiasaan makan ikan di waduk Cirata, Jawa Barat: sebagai data dasar untuk pemacuan stok ikan. Dalam Kartamihardja et al (editor). Prosiding Forum Nasional Pemacuan Sumberdaya Ikan II: 1-8.

15. Rustadi. (2009). Eutrofikasi nitrogen dan fosfor serta pengendaliannya dengan perikanan di Waduk Sermo. J. Manusia dan Lingkungan, 16(3), 176-186.

16. Syandri, H. (2004). Penggunaan ikan nilem (Osteochilus hasellti CV) dan ikan 
tawes (Puntius javanicus CV) sebagai agehayati pembersih perairan Danau Maninjau, Sumatera Barat. Jurnal Natur Indonesia, 6(2), 87-90.

17. Domalgalski, J., Lin, C., Luo, Y., Kang, J., Wang, S., Brown, L.R., \& Munn, M.D. (2007). Eutrophication study at the Panjiakou-Daheiting Reservoir system, northern Hebei Province, People's Republic of China: Chlorophyll-a model and source of phosphorus and nitrogen. Agricultural Water Management, 94, 4353

18. Yap, W.G., Villaluz A.C., Soriano M.G.G., \& Santos, M.N. (2007). Milkfish production and processing technologies in the Philippines. Milkfish Project Publication Series No. 2, 96 pp.

19. Palys, T. (2008). Purposive sampling. In Given, L. M (Edt). The Sage Encyclopediaof Qualitative Research Methods 2 Sage. Los Angeles, 697-698.

20. Yosmaniar. (2010). Hubungan konversi pakan dengan beban limbah hara $\mathrm{N}$ dan $\mathrm{P}$ yang dibuang ke air pemeliharaan. Dalam Sudrajat $A$ et al (editor). Prosiding Forum Inovasi Teknologi Akuaklutur, 681-688.

21. Tjahjo D.W.H., Purnamaningtyas, S.E., \& Kartamihardja, E.S. (2011). Evaluasi keberhasilan penebaran ikan bandeng (Channos channos) di Waduk Ir. H. Djuanda. Bawal, 3(4), 231-237.

22. Kibria, G., Nugegoda, D., Lam, P., \& Fairclough, R. (1996). Aspect of phosphorus pollution from aquaculture. Naga The ICLARM Quarterly, 19(3), 2024.

23. Beveridge, M.C.M. (2004). Cage Culture. Third Edition. Blackwell Publishing. 368p

24. Jones, R.A., Rast W., \& Lee, G.F. (1979). Relationship between summer mean and maximum chlorophyll a concentration in lakes. Environmental science and Technology, 13, 869-870.

25. Vollenweider, R.A \& Dillon, P.J. (1974). The apllication of the phosphorus loading concept to eutrophication research. NRCC/CNCR. 42p

26. Oglesby, R. T. (1977). Relationships of fish yield to lake phytoplankton standing crop, production, and morphoedaphic factors. J. Fish. Res. Can. 34, 2271-2279.

27. Almazan, G \& Boyd, C.E. (1978). Plankton production and tilapia yield in ponds. Aquaculture, 15, 75-77.
28. Welcomme, R.L., \& Bartley, D. M. (1998). An evaluation of present techniques for the enhancement of fisheries. In Petr $T$ (edt). Inland fishery enhancement. FAO Technical Paper 374: Rome, Italy: 463p.

29. Chen, S., \& Watanabe, S. (1989). Age dependence of natural mortality coefficient in fish population dynamics. Nippon Suisan Gakkaishi, 55(2), 205-208

30. King, M. (1995). Fisheries Biology, Assessment and Management. Fishing New Book. USA. 341p

31. Beveridge, M.C.M. (1984). Cage and pen fish farming: carrying capacity models and environmental impact. FAO Fisheries Technical Paper. 255. Rome. 131

32. Sukadi, M. F. (2010). Ketahanan dalam air dan pelepasan nitrogen \& fosfor ke air dari berbagai pakan ikan air tawar. Jurnal Riset Akuakultur 5(1). 1-12

33. Garno, Y. S. (2001). Status dan karaketeristik pencemaran di Waduk Kaskade Citarum. Jurnal Teknologi Lingkungan, 2(2), 207-213

34. Syandri, H., Azrita \& Niagara. (2016). Trophic status and load capacity of water pollution waste fish culture with floating net cages in Maninjau Lake, Indonesia. Eco. Env \& Cons, 22(1), 469-476.

35. Triyanto., Lukman., \& Meutia, A. A. (2005). Introduksi keramba jaring apung berlapis sebagai alternative system pemeliharaan ikan dalam keramba jaring apung ramah lingkungan di Danau Maninjau Sumatera Barat. Limnotek XII, (2), 61-67.

36. Tovar A, Moreno C, Manuel-Vez M. P., Vargas, M, G. (2000). Environmental impact of intensive aquaculture in marine waters. Wat. Res. 34 (1), 334-342.

37. Sara, G., Martire, M.L., Sanfilippo, M., Pulicano, G., Cortese, G., Mazzola, A., Manganaro, A \& Pusceddu A. (2011). Impact of marine aquaculture at large spatial scales: Evidences from $\mathrm{N}$ dan $\mathrm{P}$ catchment loading and phytoplankton biomass. Marine Environmental Research, 71: 317-324.

38. Dillon, P.J. (1975). The phosphorus budget of Cameron Lake, Ontario: The importance of flushing rate to the degree of eutrophy of lakes. Limnology and Oceanography, 20(1): 28-39. 
39. Warsa A \& Purnomo K. (2011). Potensi produksi dan status perikanan di Waduk Malahayu, Kabupaten Brebes-Jawa Tengah. Jurnal Penelitian Perikanan Indonesia, 17(4): 229-237.

40. Lazzaro, X., Drenner R. W., Stein, R. A., \& Smith, J.D. (1992). Planktivores and plankton dynamics: Effect of fish biomass and planktivore type. Can. J. Fish. Aquat. Sci, 49, 1466-1473.

41. Kartamihardja, E.S. (2007). Spektra ukuran biomassa plankton dan potensi pemanfaatannya bagi komunitas ikan di zona limnetik Waduk Ir. Djuanda, Jawa Barat. Disertasi, Sekolah Pascasarjana IPB. 165

42. Fernando, C. H., \& Holcik, J. (1991). Fish in reservoir. Internationale Reveu der Gesamten Hydrobiologie und Hydrographie, 76, 149-167.

43. Welcomme, R.L. (2001). Inland fisheries: Ecology and management. Fishing News Books, London: 358p

44. Kartamihardja, E.S \& Umar, C. (2009). Kebijakkan pemacuan sumberdaya ikan di perairan umum daratan Indonesia: Teknologi alternatif untuk meningkatkan produksi ikan pendapatan nelayan. Jurnal Kebijakan Perikanan Indonesia, 1(2), 99111
45. Cowx, I.G. (1994). Stocking strategy: Fisheries management and ecology, 1, 1530

46. Umar, C., Aisyah \& Kartamihardja, E. S. (2016). Strategi pengembangan perikanan tangkap berbasis budidaya di Waduk: Studi kasus introduksi ikan bandeng (Chanos chanos) di Waduk Sempor, Kabupaten Kebumen, Jawa Tengah. J. Kebijak. Perikan. Ind, 8(1), 21-28

47. Lorenzen, K. (1995). Population dynamics and management of Culture-based fisheries. Fisheries Management and Ecology, 2, $61-73$

48. Nwangamilo, J. J \& Jiddawi, N. S. (2003). Nutritional studies and Development of a practical feed for milkfish (Chanos chanos) culture in Zanzibar, Tanzania. Water Indian Ocean J. Mar. Sci, 2(2), 137-146.

49. Maskur., Kartamihardja, E. S., \& Koeshendrajana, S. (2010). Inland fisheries enhancement and conservation in Indonesia. in Miao W., S.D Silva. \& B Davy (eds). Inland Fisheries enhancement and conservation in Asia. FAO Regional Office for Asia and the Pacific, Bangkok, Thailand. RAP Publication, 61-76.

50. Aqil, D. I., Putri, L. S. E., \& Lukman. (2013). Pemanfaatan plankton sebagai sumber makanan ikan bandeng di Waduk 